Article

\title{
A Longitudinal Approach to Examining the Socio-Economic Resilience of the Alento District (Italy) to Land Degradation-1950 to Present
}

\author{
Rosanna Salvia ${ }^{1}$, Claire L. Kelly ${ }^{2}{ }^{\circledR}$, Geoff A. Wilson ${ }^{2}$ and Giovanni Quaranta ${ }^{1, *}$ \\ 1 Mathematics, Computer Science and Economics Department, University of Basilicata, Via dell'Ateneo \\ Lucano, 85100 Potenza, Italy; rosanna.salvia@unibas.it \\ 2 School of Geography, Earth and Environmental Sciences, Plymouth University, Drake Circus, \\ Plymouth PL4 8AA, UK; claire.kelly@plymouth.ac.uk (C.L.K.); geoff.wilson@plymouth.ac.uk (G.A.W.) \\ * Correspondence: giovanni.quaranta@unibas.it
}

Received: 6 November 2019; Accepted: 22 November 2019; Published: 28 November 2019

\begin{abstract}
Land degradation is a multifaceted phenomenon. In many mountainous and hilly areas that are marginal in terms of their economic and social sustainability, degradation is closely linked to population decline through ageing and outmigration, and to the abandonment of land, leading to a loss of community resilience. These processes acting together can produce positive feedback loops, with the consequential loss of socio-economic resilience at larger spatial scales that can ultimately lead to the disintegration of entire territories. Drawing on recent advances in defining, integrating, and operationalizing the measurement of resilience, this paper took a new approach by exploring changing resilience over an extended period in a rural region of southern Italy. The paper used both quantitative and qualitative methods to test the complex and shifting relationships between multiple domains, as an expression of spatial and temporal patterns of resilience, and examined the impact of shifting resilience on continuing degradation processes. The results suggest that the capacity of socio-ecological systems to respond sustainably to land degradation over an extended period of time is highly dependent on two critical processes: the availability and mobilization of critical factors within the five key domains noted above, and the strength of the temporal and spatial cross-scale relationships between those factors.
\end{abstract}

Keywords: community resilience; land degradation; measuring resilience; socio-economic resilience; time

\section{Introduction}

Land degradation is a complex socio-environmental phenomenon that results from the intricate interplay of biophysical and societal forces across spatial and temporal scales [1,2]. Under adverse biophysical conditions, resource-exploiting human activities can set in motion processes of degradation, yet land degradation may also be reversible (within relatively short timeframes) through human interventions. However, if degradation is uncontrolled, entire landscapes can deteriorate, leading to impacts on ecosystem services, which in turn give rise to unwanted or negative socio-economic impacts at multiple spatial scales [3].

Human interventions undertaken in response to and to prevent land degradation issues aim to slow down or stop the deterioration of land resources, restoring the vitality of ecosystems and supporting better human and environmental conditions in affected regions. Such interventions originate either locally (e.g., through sustainable land management practices) or at higher spatial scales (e.g., through national policies and international conventions) [4]. 
One helpful approach to understanding socio-environmental problems such as land degradation is the complex adaptive systems (CAS) paradigm [5,6]. The CAS paradigm recognizes the inseparability of these systems, their nonlinear component relationships, and the existence of positive and negative feedback mechanisms that help to account for their dynamics. Responses to land degradation, therefore, need to be studied in relation to, and not in isolation from, the wider systems in which they are embedded. Following the CAS paradigm, the overarching goal for human responses to problems such as land degradation is the protection and retention of the resilience of the regional system as a whole, as well as the individual resilience of the communities that constitute that system [5].

In order to understand why some systems and communities either respond weakly to, or fail to cope with challenges (exhibiting low levels of resilience), it is imperative to understand how available resources are mobilized and used [7-9]. These resources are grouped into five broad domains: social, cultural, institutional/political, economic, and natural [10]. The social domain includes networks of interactions between individuals and groups, human skills, and knowledge. The cultural domain encompasses society's historical memory and experience, the arts, and ideological standpoints. The institutional domain reflects the inclusiveness of the political process and/or the extent of democratic processes; the economic domain is the monetary and financial basis of the system; and the natural domain reflects how well-endowed a society is with resources such as soils, water, or mineral resources. The interplay of factors within these domains and changes in their availability over time are, we argue, reflected in changing levels of resilience and provide key explanations about differences in the impacts and management of challenges such as land degradation.

The underlying premise for the approach taken in this paper, and the key knowledge gap that this paper tackles, was that there is an optimal "balance" between the five domains of a socio-ecological system that enable the system not only to persist but to thrive over time. Our assumption was, therefore, that where land degradation problems become established, the interplay between various factors within domains, or indeed between the domains, is out of balance. Pragmatically, we acknowledge that in real-world contexts, the issue is likely to be a problem with the way that "people" interact with and use environmental resources, but what is not clear is where the imbalance originates. Is it through national or regional-level institutions (laws, policies)? Or are macro-scalar environmental changes (climate) or changes in the global economy the origins? Or, perhaps more likely, is it a combination of all of these things? Current assessments of resilience inevitably lean towards assessing and evaluating change in the short term and/or in the human elements of the system, because it is more likely that these are where the main problems lie, and where positive change can be made to happen (in theory at least). However, if we are to understand where successful interventions lie, it is important to map change and identify the origins of imbalance over a much longer timescale.

\section{Socio-Ecological and Community Resilience}

Resilience in general is about the ability of a system to absorb impacts and/or disturbances, to re-organize into a fully functioning system, and about post-event adaptive processes. Holling [11] popularized the term "resilience" in the context of ecosystem stability. Since then, many scholars have taken up the term and developed it as a lens to understand a wide variety of contexts (see, for example, References [9,12-25]). Importantly, resilience does not necessarily imply a return to the pre-existing state; resilience also refers to the ability to respond to opportunities that arise as a result of change [26].

Resilience is usually seen as the opposite of "vulnerability" [9]. In that sense, resilience is a normative concept, i.e., an end-point or a goal that policy- and other decision-makers can strive to achieve $[27,28]$. Managing for resilience therefore implies that a system can, theoretically at least, be manipulated in order to influence it to change to a more desirable resilient state, or to prevent it from changing to a less desirable or vulnerable state [20].

Socio-ecological resilience (or SER) is a term used to refer to spatial scales above the local, and is seen as providing a linking concept between social and environmental science fields [29]. SER is 
a function of the adaptive capacity of the complex and interdependent socio-ecological system (SES). Community resilience (CR), on the other hand, relates to the local or community scale and encompasses the human and non-human resources and capacities able to take collective action to deal with problems and determine future development trajectories [30]. In this way, both SER and CR include consideration of system characteristics and the processes through which human agency identifies and shapes future trajectories. As Folke et al. (2010) [31] noted, resilience is about people and nature as interdependent systems. The consideration of scale, both spatial and temporal, is critical when assessing the resilience of socio-ecological systems. The temporal and spatial scales at which natural resources are managed by humans, and the scale at which policy analysis is generally undertaken, are often at odds with the scale(s) at which these processes actually operate in the real world [32-34].

Regardless of the spatial scale at which it is applied, resilience refers to the interplay of a suite of factors, the specific configuration of which, at any given moment in time, defines how the CAS behaves. Understanding resilience is, therefore, not about understanding one aspect of a system; it is about understanding the whole system and how changes in the balance between one set of factors impact other factors and influence human decision-making. In addition, differences in speeds of spatial processes within the SES mean that human communities are never "stable", but are continuously and simultaneously affected by multiple changes at any point in time. This adds another layer of complexity to understanding the resilience of an SES, and highlights the importance of taking a diachronic or longer-term view to understand how and why changes in resilience happen.

\section{Land Degradation and Resilience}

Resilient socio-ecological systems and communities are characterized by well-developed resources that support positive, adaptive responses, and include actors who are able to draw on local resources to respond to challenges [6,11]. In the Alento district of southern Italy, upland land degradation processes, namely soil erosion, landslides, and scrub encroachment, are closely associated with long-established cropland farming systems, based primarily on wheat and olive production. While there is evidence that extensive cropland systems can be sustainable (both in environmental and livelihood terms), modern production-orientated methods can lead to substantial soil erosion and land degradation [35-38].

In socio-economic terms, some cropland regions and their associated communities are better integrated into export-oriented systems, meaning that they include well defined "horizontal" (i.e., within communities/regions) and "vertical" (i.e., between communities/regions and the wider value chain) links and networks, which can make the identification of key drivers of change difficult $[39,40]$. A longitudinal approach is, therefore, needed in order to trace changes in these networks to discern the extent of their impact on SER.

Assessing the relationship between resilience and land degradation is further complicated by the fact that complex and fragmented land ownership patterns (owned, absentee, or rented) make identification of the relevance of individual factors more difficult. These context-specific factors are important because, in this case, landscape-level resilience to land degradation is often shaped by macro-scalar processes and decisions made far from the land itself, or at higher spatial levels and over which local stakeholders may have little direct control.

One such macro-scalar process is demographic change. Outmigration is an important response to economic and social change, especially if the prevailing economic context is no longer able to sustain local communities. Linked to outmigration, the process of land abandonment is also feedback-related, with the resulting abandoned land acting as an additional trigger for further land degradation through loss of terrace maintenance further up-slope and changes in vegetation cover that can affect soil quality, although positive effects linked to natural or native vegetation regrowth that protects soil structure can also be evident. In the Alento, as in other areas, social and economic policy approaches such as supra-national rural development initiatives have attempted to address outmigration and land abandonment, although success in maintaining populations in the most remote and marginal areas has 
been mixed [10,41]. Agri-environmental measures have had some positive impacts by providing "green subsidies" that have, at least partly, helped to keep some families in their communities, although these have not always been focused on actions that are wholly appropriate in cropland areas [42].

\section{Methods}

This paper made a novel and important contribution to operationalizing the assessment of resilience by testing a mixed-method approach to detect changes in key resilience components over an extended period of time.

\subsection{The Alento Socio-Ecological System}

The methods used in this research examined macro-, meso-, and micro-scalar changes in the Alento (an area with significant primary agriculture as well as secondary agricultural processing industries) over an extended 65 year period from 1950 to 2015 (Figure 1). There have been several significant slow- and rapid-onset challenges in this area over the last 65 years, and this time span was chosen to identify how these national- and regional-level changes have influenced SER and CR. The Alento district is a paradigmatic example of the changes happening in many interior regions of Italy (Alps and the Apennine) and, more generally, across Europe as a whole, and include agricultural modernization, migration and population change, urbanization, industrialization, and post-industrialization [43].

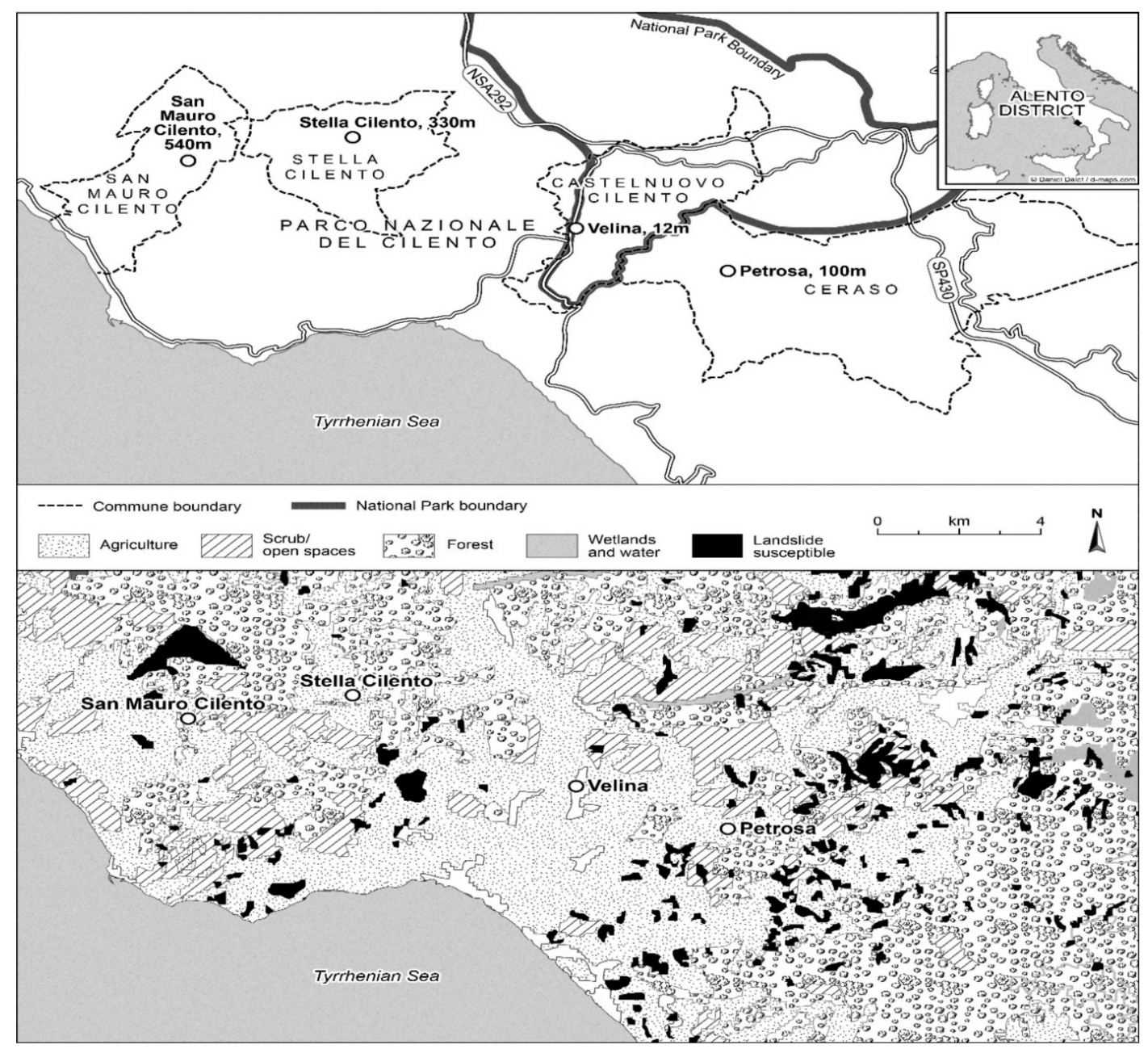

Figure 1. The Alento district with the four case study communities, main land use types, and landslide-susceptible areas (Source: authors; after Reference [40] and CORINE Land Use Classification, 2006). 
Four communities were chosen in the Alento district: Stella Cilento, San Mauro Cilento, Velina, and Petrosa. Two communities; Stella Cilento and San Mauro Cilento, are upland communities located within the boundaries of Cilento and Vallo di Diano National Park (established 1991). The principal land degradation problem facing these upland communities is soil erosion, which reduces agricultural productivity and, in the most severe cases, leads to landslides, which pose a serious threat to local infrastructure. Given the hilly terrain in these communities (e.g., gradient values $>50 \%$ on more than half of the agricultural land in Stella Cilento), slope instability is a serious concern, and abandoned or collapsing dry stone terraces pose a real threat with severe impacts on topsoil. Another driver of erosion in these communities is forest fires and, as abandoned olive groves border on forests, fires originating in wooded areas spread fast and can exacerbate already existing soil erosion problems. The communities of Velina and Petrosa, on the other hand, are located on the flat, fertile valley floor. Land use in the community of Velina is characterized by intensive farming and extensive irrigation, making it susceptible to soil sealing, nitrate pollution, and salinization. Socio-economic issues associated with population influx, coastal development, and urbanization, in particular, have contributed to soil quality-related issues in this community. In Petrosa, agricultural land use is generally less intensive, with reduced incidence of soil erosion, soil sealing, and salinization, although the threat of nitrate pollution is present.

All four Alento communities suffer from land degradation issues to varying extents, related to both human and natural drivers of change. Agricultural land covers about $60 \%$ of the four case study communities, with olive groves, pastures, and chestnut groves prevalent in mountainous areas, and permanent crops, fruit orchards, maize fields, and vineyards the dominant land use types in the lowlands. Planted or natural forests (beech and oak forests) cover the remainder. The average farm size is only 2.4 ha, highlighting that generating sufficient income from farming is difficult, with many part-time farmers and high levels of pluriactivity as a result. In addition, the Alento district is characterized by pronounced land fragmentation, and although agricultural production has been boosted through the establishment of local cooperatives and associations, fragmentation and a lack of family farm succession has reduced agricultural profitability and modernization.

\subsection{Methodological Approach}

There are a number of different approaches as well as a multitude of specific methods in the literature, across various fields, for "measuring" the resilience of an SES. As noted above, complex interlinkages between natural resources, social and economic factors, and resilience can only be fully understood through a multi-method and multi-scalar approach that combines information from both qualitative and quantitative data sources [9]. This enables cross-checking and iterative validation using different data sets to identify how and why the local and regional contexts have changed.

In order to sort and organize the multitude of events and processes impacting over the 65 year time period across the various spatial levels, the research team developed a narrative of the area using a wide range of primary and secondary data sources. As Becker (2000) [44] argued, events and outcomes are not independent of each other, and may impact unevenly and at different points in time as events unfold. Multiple variables, therefore, have a dependent temporal and spatial quality, which influences the resultant outcome. Given the complexity of interdependent variables, Becker (2000) [44] therefore suggested the use of narrative analysis as a method to capture the processes by which various outcomes are produced over time. The term "narrative" is used here to mean the collection and integration of information from multiple sources into a temporally organized whole, which then provides an opportunity to identify the influences that have shaped the particular path taken [45].

Drawing on a range of quantitative and qualitative methods, the research was structured in three stages:

1. Exploration of the evolution of the socio-ecological system over the period of assessment and identification of periods of stability and periods of transition; 
2. Analysis of the impacts of macro-, meso-, and micro-scalar events and trends on land degradation processes;

3. Identification of the specific economic, social, natural, cultural, and political/institutional factors that have driven the observed changes in resilience to land degradation

In Stage 1, the evolution of the system was identified as either stable, in which the biophysical and socio-economic characteristics remained more or less constant, or in transition, in which the characteristics of the system were in flux before a new stable state was reached [46]. Using this approach, three separately characterized periods were identified: (i) migration and efficiency imperative (transition), (ii) local off-farm jobs (stable period), and (iii) land abandonment (appears to be in transition). In order to identify temporal boundaries and delineate each period, two variables were used: utilized agricultural area (UAA) and population [47].

In Stage 2, detailed qualitative and quantitative data were collected to identify events and trends occurring across all three spatial scales (macro-, meso-, and micro-) and to understand the impact of these events and trends from a range of different stakeholder perspectives. In addition, any spatial variation in impact was also identified, to assess whether gradients of change existed across the SES [48]. In Stage 3, the impact of the events and trends identified in Stage 2 were assessed for their ability to increase or decrease the ability of the SES to cope with land degradation during the period of study and to characterize the origin of "imbalances" in domains which had led to the diffused erosion, landslide risk, and scrub encroachment. The specific methods used are discussed below.

\subsubsection{Quantitative Methods}

Quantitative data were collected from a broad range of secondary sources and used to identify specific periods of stability or transition within the SES, and to explore patterns and trends which might account for those periods [47]. Historical and statistical records, official reports, legislation, and other important secondary data were used to quantify the various factors within the social, cultural, political/institutional, economic, and natural domains. At this point, some factors were not considered further as they showed no significant change in the time span considered. For each measured characteristic, a trend value was calculated in each period, enabling identification of increasing, decreasing, or stable patterns. For a complete list of the characteristics used, see Briassoulis [47].

Table A1 (Appendix A) shows the range of quantitative data collected, as well as the specific factors which showed diachronic changes. Tracing the changes in these factors allowed us to triangulate changes occurring in the system across multiple data sources. Qualitative analysis was then used to explain the impact of diachronic changes and to help avoid mechanistic and linear assessments by anchoring the analysis of resilience to the perceptions of different stakeholders and stakeholder groups. These two parts of the analysis converged and reinforced each other, allowing for an "internal" (to the SES) assessment not only of the quantity of specific factors at different points in time, but of their accessibility and "quality" from different stakeholder perspectives. This holistic analysis allowed us to identify the processes that enable or disable agency and action in the SES [9,29].

\subsubsection{Qualitative Methods}

Qualitative data were collected first through 46 semi-structured interviews with a range of community (43) and regional (3) stakeholders, and then through four focus groups (one in each community, approximately 15 participants in each group) with stakeholders with interests and expertise across a range of relevant subjects and at various spatial levels. All data collection was conducted in Italian. Data sets were transcribed verbatim and subsequently translated into English. Sets of interview questions were grouped into four broad themes (preliminary questions, economic issues, environmental issues, social issues). Interview schedules were tailored specifically to stakeholder types and particular areas of expertise. Interviewee responses to the preliminary question themes provided a general 
understanding of land degradation issues, as well as the broader social, environmental, and economic issues affecting the region and/or the local area. The economic, environmental, and social question themes then offered an opportunity to explore these issues in more depth and from a range of different perspectives. In particular, the researchers sought to engage interviewees in a reflexive discussion about land degradation and its relationship to the broader changes that had occurred in the SES over the past 65 years, and to consider alternative viewpoints to their own.

The key issues that emerged from the interviews were then used to structure focus group discussions. Participants for the focus groups were a range of individuals representing local and regional political and administrative organizations, businesses, and land uses (such as farmers and olive producers), as well as land management professionals. Participants included those who lived and/or worked in the region and in the selected communities, together with individuals and organizations that had an interest or were engaged in policy and practical actions associated with managing and responding to land degradation issues in the SES. Selection of participants was not limited to those who had been interviewees. As noted above, the quantitative and qualitative data analyses were combined in Stage 3 to explore how various factors in each domain had changed over time, and how that had impacted on the resilience of the SES and its constituent communities to cause land degradation.

\subsection{A Note on Limitations and Issues}

Inevitably there are practical and philosophical problems associated with the quantification of resilience. Further, it may be relatively easy to quantify change in some factors where there is likely to be little cultural difference in interpretations of whether they are "good" or "bad" for resilience. However, with many factors, the distinction between good and bad is not straightforward, and depends on different stakeholder viewpoints. In order to counter this, participants were selected from a range of different stakeholder groups both within and outside of the case study communities. Iterative data collection, along with cross-checking and triangulation between data sets and data types (qualitative and quantitative) was important to ensure that we included as full a range of perspectives as possible.

In addition, the analysis assumed that all factors across all three domains had equal value and were directly comparable although they are likely to be based on different temporal and spatial scales. We posit that the results can only be interpreted in a wider context of local expert knowledge about past and present pathways of change in the Alento, and it is therefore critical to use both quantitative and qualitative methods and data sets in order to contextualize the longitudinal changes that have led to the specific land degradation outcomes and associated changes in resilience that we saw on the ground.

\section{Analysis: Three Key Time Periods and the Resilience of the Alento District}

The starting point for analysis was the economic, social, and environmental transition of the early post-World-War-II period. At the end of the 1940s, the local area remained relatively unchanged from the previous century, particularly in terms of infrastructure and economic activity $[49,50]$. The Alento remained an isolated and marginalized area, existing in economic, institutional, and cultural stasis [51,52].

\subsection{Period 1-1950s to Late 1970s (Migration and Efficiency Imperative-Transition)}

This first time period, identified as the "migration and efficiency imperative" (Figure 2), was a time of significant transition in the whole of Italy. The period started in the 1950s, when the Alento experienced much the same trends as those seen across southern Italy (rural out-migration to industrialized centres during the post-war economic revival), and ended in the 1970s, when the agricultural sector underwent dramatic reorganization both in terms of modernization (as part of the Mansholt Plan in 1972) and in terms of its size and economic importance in the local economy. 


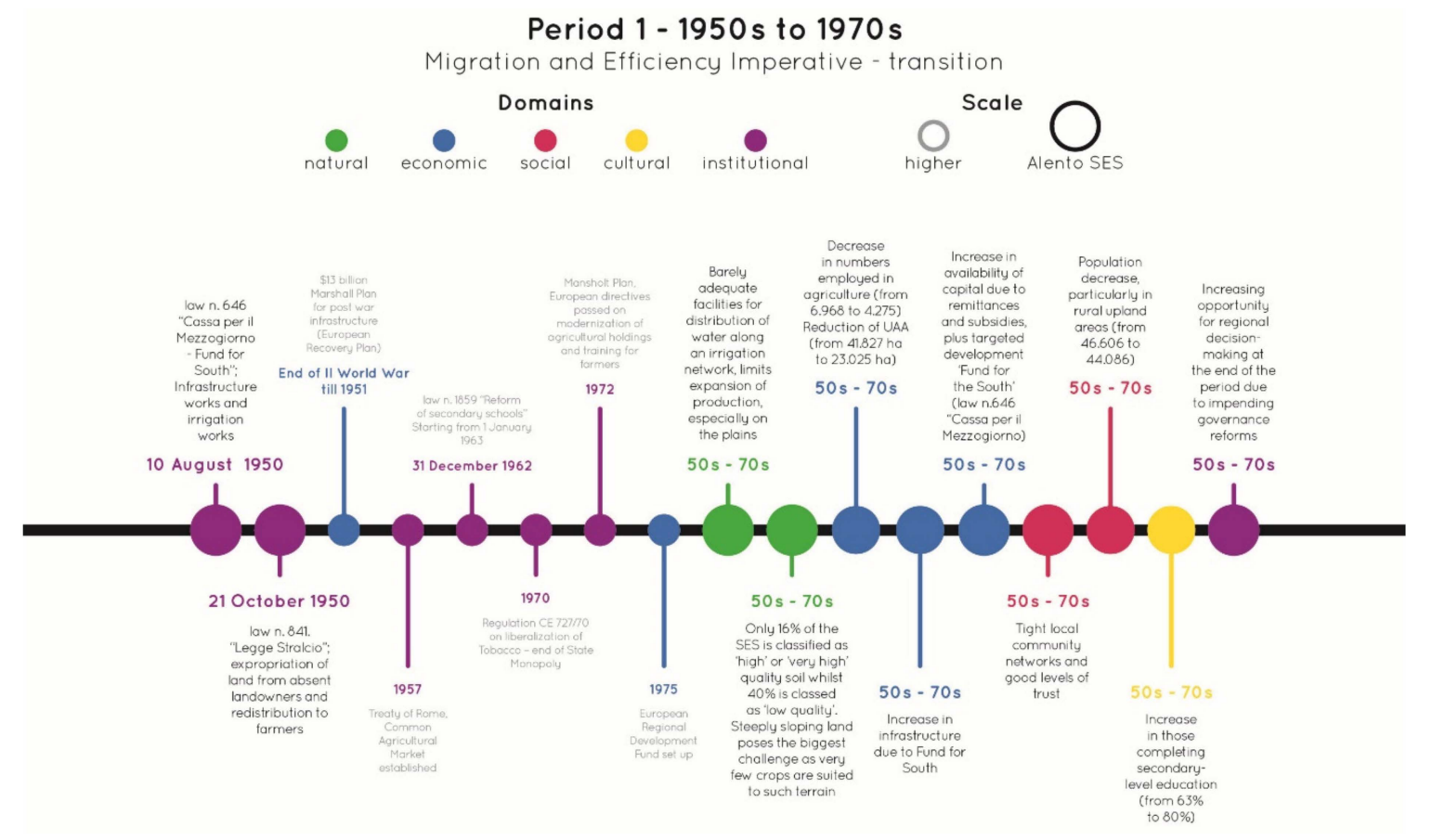

Figure 2. Period 1-1950s to Late 1970s (Migration and Efficiency Imperative-Transition). Source: Authors.

See also Table A2 (Appendix A) for the list of the factors assessed.

During this period, the SES underwent a profound restructuring of its production base. Emigration and land abandonment on one hand, and the drive for modernization in the farming sector on the other inevitably squeezed the most marginal farms out, resulting in a 50\% reduction in utilized agricultural area (UAA). Unusually, the contraction of UAA was not accompanied by a reduction in the total number of farms, but a substantial part of the labor force was reduced. A farmer from Petrosa explained the way life had changed during this period:

"In the past, this community had a strong rural economy thanks to livestock farming and the cultivation of tobacco and grain; it provided lots of jobs for locals and even for the surrounding towns and villages. Things started to decline in the 60s and 70s when there was an economic boom and emigration soared. [...] In short, in the past the town was productive and people lived very simply, without the technological advances of today, but they lived well."

In structural terms, the SES was characterized during this period by highly fragmented farms (high numbers of very small farms) and large estates [53]. The demand for land, which was very high at the beginning of the period, was generally not met due to the rigidity of the local land market, although steps were taken at the national level to develop laws (Law 21 October 1950, n. 841; 'Legge Stralcio') to expropriate land from absentee landowners and redistribute it to local farmers who needed it [54].

Despite the reduction in the UAA, the volume of production during this period was "balanced" by increased yields and better market integration. Financial components also played an important role, in that lines of credit together with an increased flow of remittances and subsidies into the SES contributed to increased profitability. Better infrastructure and technology also supported increased productivity by enhancing system connectivity with external areas through access to external markets, and by introducing new agricultural inputs with the power to exponentially increase production. At this point, only water availability and poor irrigation networks limited production for communities such as Velina and Petrosa in the plains.

In the upland communities of Stella Cilento and San Mauro, traditional transhumance-based livestock farming practices, which depended on land ownership in both the uplands (summer grazing) 
and lowland plains (fodder production) began to cease. These geographically linked practices had been an important connection, together with the joint management of the "levate" (rudimentary dug-out water canals), between the inland mountain areas and the coastal plains. Although the water regulation framework in each community which governed the use of surface water continued to be enforced, it was progressively undermined by the breakdown in community relations and more modernized production methods.

With the introduction of more intensive cultivation models and the demand for more land on the plains for commercial crop expansion, the traditional links between the two areas were weakened further. Monocultures and intensification also reduced internal connectivity between small farmed plots of land, thereby reducing the traditional "mosaic" element of mixed farming. With this modernization of agriculture, soil management began to lose its connectivity with other farming activities (especially the use of livestock manures for increased soil fertility), and external inputs (fertilizers and pesticides) became the norm. On the plains, where the state had a monopoly on tobacco production until the 1970s (Regulation CE 727/70 ended this monopoly), the precariousness of the system had already begun to increase.

Soil types also significantly limited cultivation choices and therefore the expansion of intensification. Only $16 \%$ of the SES was classified as "high" or "very high" quality soil. Steeply sloping land posed the biggest challenge to intensification. As a result, the introduction of mechanization in the SES was met with strong resistance in upland areas, where these new technologies were wholly unsuited to the terrain. As one farmer in Stella Cilento noted: 'Yes, the land is too steep to be farmed and so farmers can only use that land for crops that don't require farm machinery.'

The demographics of the SES were still heavily shaped by emigration during this period. Outmigration was primarily male and from rural communities. Population figures showed the greatest depopulation from inland hilly areas, rather than from mountain areas or the plains. The choice to emigrate was influenced by rapid industrial development in the north of Italy and northern Europe. People in isolated upland areas also chose to move down to the plains and coastal areas, which were better connected and offered better services and opportunities. The reduced pressure on land following emigration did, in fact, calm the social tensions which had started at the beginning of this period, but in inland areas, where depopulation was most pronounced, there was a significant reduction in land and terrace maintenance and a shift to a more elderly population. As a result, some of these communities struggled to recover in terms of their long-term development.

The changes occurring in the SES had a more positive impact on cultural factors during this period. The literacy rate increased exponentially and methods of knowledge transfer were transformed as schools began to play a more central role and knowledge became more formal and structured. Even though this process affected only the younger generation in the study site, and education remained quite basic (compulsory secondary education until the age of 14 was officially introduced in 1923, but did not impact until 1963 with the reform of secondary schools), it had a significant impact on rural areas. The combined effect of greater education and the cultural shift which followed started a rural/urban dichotomy which was much more pronounced in Italy than in other European countries [55].

Up to this point in Italy, modernity and modern lifestyles had been exclusively associated with urban areas and, particularly in southern Italy, rural areas were considered backwards and culturally resistant to change [51]. The traditional role of the rural family as a collective point of reference and the essential nucleus of the society [56] began to be questioned, as was the entire value system of rural society. The close, cyclical link between farming and natural resources (production, processing, consumption, reintegration of organic residues, new production) began to be challenged by the modernization of agriculture, which not only impacted the sector itself but also tied in the local system to external markets (for fuel, fertilizer, and prices, for example). Traditional farming community rituals, superstitions, and beliefs associated with the land and production cycles lost importance and, although they did not disappear altogether, were considerably marginalized. The 
social domain also changed greatly in this period in terms of both bonding capital and bridging capital. There were several factors behind this change. Firstly, changes in housing availability: many families moved out of cramped houses in the centre of the community into modern houses or apartment blocks outside of village centres. Secondly, emigration and the breakup of multi-generational family units. Thirdly, the disappearance of traditional practices like job exchanges, local livestock breeding (which brought livestock farmers from various communities together), and transhumance gradually broke the centuries-old connections between mountain communities and plains communities.

In terms of institutions, the SES was still characterized by strongly centralized top-down policies in this period. Policy actions were funded entirely or partially by the state, and were conceived and designed with little or no understanding of the specific context of the SES, a fact which significantly hindered the effectiveness of these interventions. The state was later seen to have had a "perverse effect" during this period, in that southern Italy was perceived as having accumulated wealth but not having succeeded in freeing itself from its dependence on state aid [57]. The overall effect of this was to unbalance the relationship among domains, creating an overly strong focus on growth within the economic domain which was not based on the capacity of key local resources, and which weakened equity in the social domain. As a result of this focus, the pre-conditions for accelerated land degradation were set in motion, although the impacts on natural domains were not yet evident.

\subsection{Period 2-1980 to 2000 (Local Off-Farm Jobs-Stable State)}

The second period, identified as "local off-farm jobs" was from 1980-2000 (Figure 3). This period was one of relative stability, with the growth and consolidation of new tourism markets, including agri-tourism, and the construction of major infrastructure projects. Of significant importance during this period were improvements to water supplies for both agriculture and tourism through construction of a series of dams in the area that, in turn, also boosted other sectors such as the construction industry.

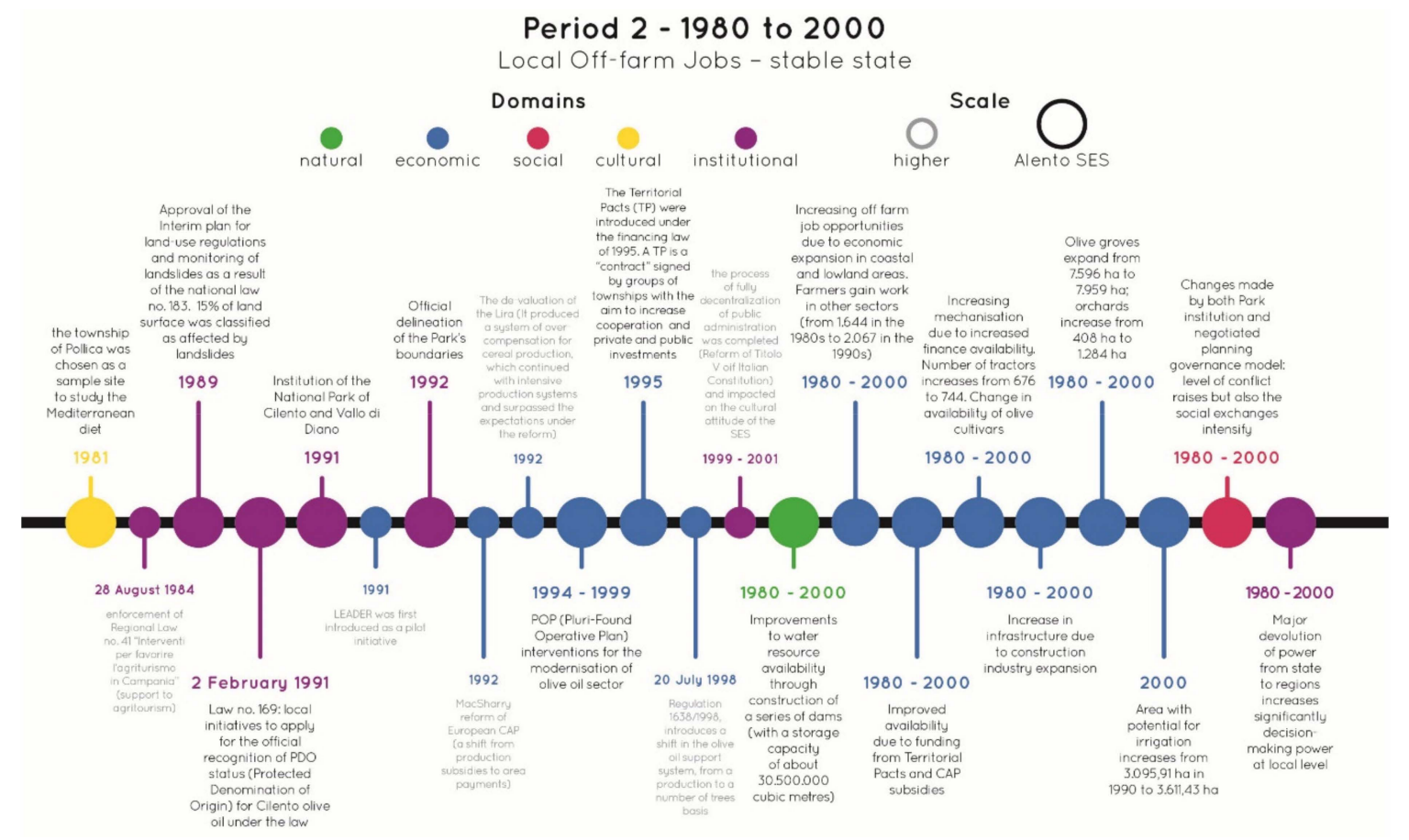

Figure 3. Period 2-1980 to 2000 (Local Off-Farm Jobs-Stable State). Source: Authors.

See also Table A3 (Appendix A) for the list of factors assessed.

The reorganization of the agricultural sector, which began in the previous period, was consolidated during this period, and water availability, a limiting factor in the previous period, now became the critical 
component driving change. The construction of large-scale dams in the area provided an opportunity for agricultural businesses to experiment with new crops and systems (in commercial-scale greenhouses), particularly on the plains, where water availability had previously limited crop innovation.

Olive production expanded in the SES and, due in part to changes to subsidies and the availability of new technologies, production intensified. Increasing mechanization and the decline in the agricultural labor force continued in this period. However, new, higher-yielding olive cultivars, introduced to generate bigger EU subsidy payments (which were linked to yield rather than quality) had a disastrous effect on the quality of local oil production. New cultivars were also much more vulnerable to local pests and diseases, requiring increased pesticide use [40]. The new irrigation systems in these areas also provided ideal breeding conditions for insects, which led to further pesticide use and caused damage further inland to olives in areas which had not previously been infected. This positive feedback loop between the new olive subsidy regime, the availability of new technologies, and the replacement of traditional pest-resistant but lower-yield cultivars resulted in an increased dependence on imported materials and resources, such as agri-chemicals and machinery, and a concomitant decline in the availability and use of local knowledge and production skills. These and other regional economic impacts continued to be felt on small, mixed family farms:

"Before the 1960s and 1970s farming was considered a vital source of income for the local economy, families didn't just get by but lived well from farming. Farmers were also pretty self-sufficient and any surplus production was sold on the markets. [ ... ]. Today farmers can't even get by on what they make and need alternative incomes." Food producer, San Mauro Cilento.

The expansion of other economic sectors, as well as the development of the tourism sector, ensured that coastal and lowland areas continued to develop, creating a flow of financial resources into many small family-run farms, which was generally re-invested into agriculture. Added to this was the ready availability of EU subsidies for bulk olive production and a new, more flexible banking system. The level of technology used on farms continued to increase, driven by agricultural development funding available through EU structural funds, although these opportunities were not always taken up by small family-run farms:

"... many farmers hardly think it's worth their while to apply for [ ... ] funding. The cost of the technicians and the time needed to complete the application discourages small farmers";

"Farmers with little land often do not apply for the single payment, feeling that there is too much bureaucracy surrounding the process." Financial Planning Advisor.

Increased mechanization also enabled more of the labor force to fit agricultural work around off-farm jobs, thereby buffering families against changing market prices.

The dependence on technology impacted farm debt levels, but was largely masked by relatively high market prices, the availability of subsidies, and off-farm income. Local specialist food manufacturing remained one of the biggest regional employers (olive processing and food manufacturing accounted for $40 \%-50 \%$ of the total agri-food sector) leading to further economic dependence on this sector. These "lock-ins" resulted in a high degree of vulnerability in the system, although counterbalanced to some extent by high levels of part-time farming and the financial safety net provided by the state welfare system.

Production of low-quality olive oil was buffered during this period by big national brands blending production and, as a result, the level of integration with regional and higher-level markets continued to increase. These two key factors meant that the SES was in a weak position in relation to supply chains at higher spatial levels, as added value was only created when products moved out of the SES. Better integration did, however, result in a closer link between the SES and horticultural production in other regions, which allowed for the transfer of specialist knowledge into the SES and the inclusion/positioning of products within a consolidated distribution chain. Conversely, it also left the SES exposed to dynamics, processes, and decisions made at higher spatial levels. 
In institutional terms, this period also saw major change in the role of the state in policymaking. Significant changes were made to Italy's institutional structure, marking the start of a process of administrative de-centralization. After the de-activation of the Cassa del Mezzogiorno (Fund for the South) early in the 1990s (with Law no.448 1992), public intervention works in disadvantaged areas entered a new phase which was centred on streamlining interventions through public/private partnerships [58].

As a result of the institutional reforms, a new approach to economic policy also emerged, explicitly directed towards the formation of local development, in part on the back of significant reforms to EU structural funds. A "bottom-up" approach was favored and interventions were, for the first time, based on actors' capacity to cooperate. One of the principal instruments, introduced with negotiated planning under the financing law of 1995, was the Territorial Pacts (TP) Act, a contract signed by groups of townships in a common geographical area, with the aim of increasing cooperation between local economic partners, increasing the flow of private investment into the area and sparking a process of economic growth in under-developed areas. In the Alento, there were two TPs (the General Territorial Pact of Cilento; and the Specialized Territorial Pact for Agriculture and Fishing of Cilento) that financed 111 business initiatives, as well as significant work to infrastructure in support of productive activities, such as improvement to water systems in coastal areas and the creation of productive industrial zones. Nearly two decades after these interventions, the general opinion on their effectiveness remains rather negative. One of the principal weaknesses of the Pacts was local communities' lack of a strategic vision and the heavy focus on the construction of infrastructure for agriculture, which proved fruitless, as the high costs of management were completely disproportionate to the effective economic output of the local agriculture sector.

The creation of the Cilento and Vallo Di Diano National Park in 1992 also affected the structure of local governance during this period, introducing participatory mechanisms, such as the consultative body "Community of the Park", that offered the potential for re-establishment of traditional but weakened community links and a reduction in tensions created by the establishment of the Park, alongside locally-based governance processes [40]. Despite this more participatory approach, however, there was little evidence of better social cohesion in the area, due to a long-entrenched lack of capacity, failure to address long-term issues, and, ultimately, the incapacity to bind the community together. The power lobbies that were established and consolidated in the previous period were strengthened in this study period and the new planning instruments did nothing to increase inclusivity. As a civic official in Petrosa noted; "neighbors don't really trust each other, there is a culture of individualism, everyone looks after their own interests first."

During this period, the rate of emigration slowed and some emigrants began to return, resulting in a stabilization of population flows. However, as a result of previous depopulation, rural areas continued to be characterized by ageing populations and low rates of family farm succession. Young people chose not to enter farming as other sectors offered better opportunities elsewhere. This trend began to lead to the loss of traditional agricultural and environmental knowledge and skills (for example, maintenance of terraces, understanding local weather patterns and catchment dynamics), as knowledge and skills were only partly passed on [40,41], even though there were some National-Park-led and EU community development initiatives (such as LEADER) that, together with the valorization of the Mediterranean diet (UNESCO patrimony) tried to document and catalogue traditions, skills and customs in an attempt to recover and preserve local distinctiveness. Although re-discovery of local culture offers the potential for change, its translation into new economic activities is still weak and will take some time to establish. Levels of formal education continued to increase and the percentage of the population with a university degree almost tripled in this period, but choices of degree subject were almost entirely outside the agricultural sector, weakening the linkages with SES resources and their exploitation.

In terms of agricultural production (economic domain), the effects of declining soil quality and associated soil erosion (due to land abandonment in upland areas and lack of terrace maintenance) 
were mitigated by advances in agricultural technology and the availability of synthetic inputs, highlighting the ability of factors within a domain to shift relative to each other. On the face of it, this small shift was balanced within the domain but, as the impacts of abandonment were felt more strongly in the natural domain, this shift nonetheless led to the system as a whole becoming more vulnerable due to enhanced landslide risk. This increased risk was at least recognized through initiatives to identify and delineate areas vulnerable to landslides. In reality, however, little practical action was taken to address the problem, underling the impact of inefficient and weak development of policy action in both institutional and social domains.

\subsection{Period 3-2000-2015 (Land Abandonment-Transition)}

This third period, from 2000 to 2015 (Figure 4), saw a structural crisis in the olive production sector, which reached a significant state of decline towards the end of the period, with problems exacerbated by subsidy reform and the introduction of the Single Farm Payment Scheme.

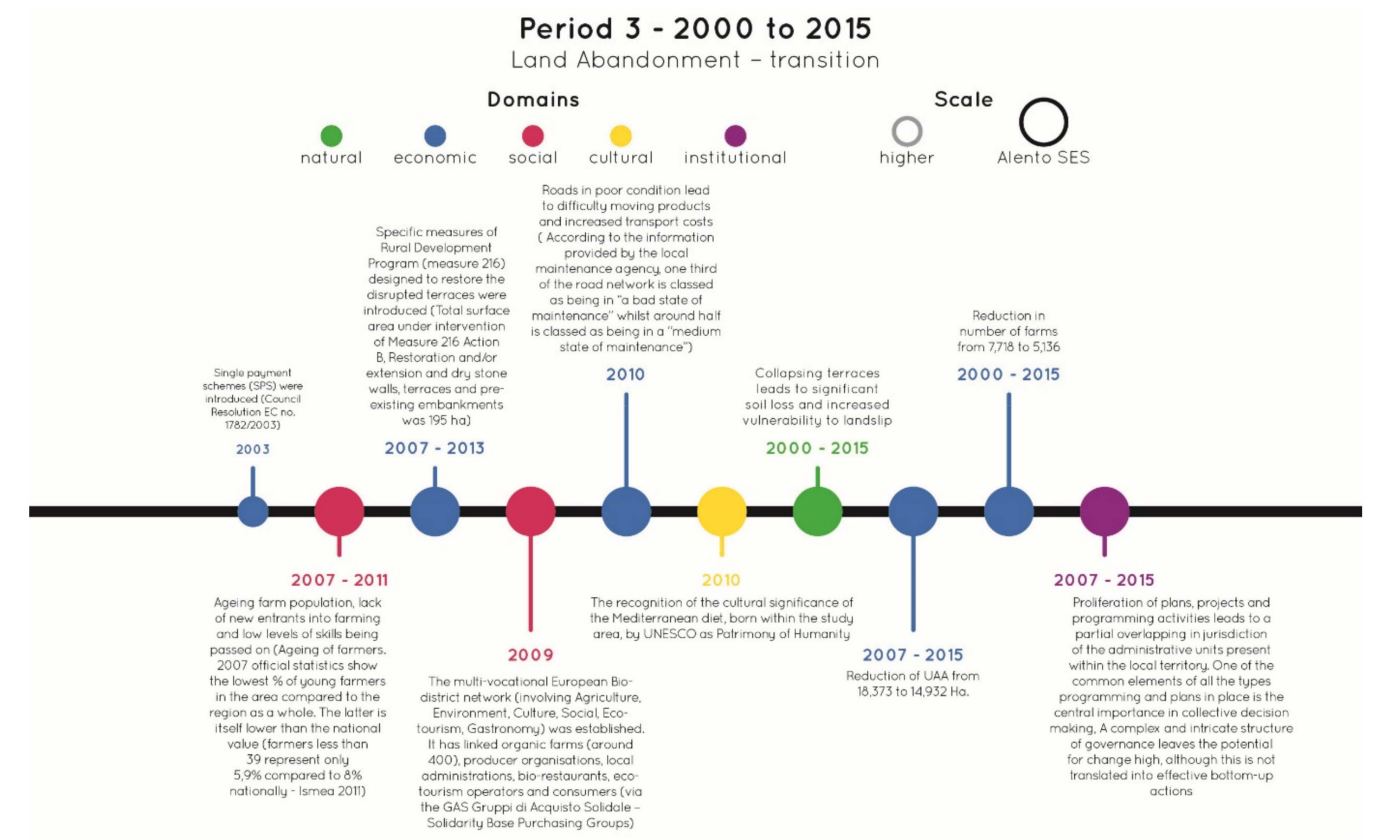

Figure 4. Period 3-2000-2015 (Land Abandonment-Transition). Source: Authors.

See also Table A4 (Appendix A) for the list of factors assessed.

The extent of land under agricultural production reduced significantly in this period, being halved over the course of the decade and, for the first time since the 1960s, the number of farms reduced by over $30 \%$ (a drop of around 2600 farms), although the value added (VA) in the agricultural sector remained high, accounting for $5 \%$ of the total VA of the SES, around double the regional average.

The availability of financial resource started to reduce; changes to CAP subsidies and a significant reduction in state funded infrastructure and development all contributed to a realignment of the economic profile of the area.

The establishment of organic olive production, however, created pockets of potential for innovation and change in a few areas of the SES. The move to organic farming, especially in inland areas, enabled these farmers to access new and higher-value niche oil markets and reduce their dependence on large-scale regional oil processors. Despite these small improvements, however, CAP subsidies, despite remaining at the same level, were no longer able to offer sufficient financial support to the majority of famers, given the decreasing margin between production costs and market prices.

In terms of demographics, population figures remained stable in the study period, although ageing continued to rise in rural areas and selective migration flows reappeared, with the youngest and best-educated most commonly migrating out of the SES, further weakening already stretched service 
provision in rural inland areas [40]. Adding significantly to the general problem of population ageing was the lack of succession in the mainstream agricultural sector. Discussion with local stakeholders revealed that young farmers feel they are not given enough opportunity to participate in decision-making processes. Many stakeholders lamented the lack of an "entrepreneurial mind-set" in their communities, blaming excessive bureaucracy as a barrier to setting up new businesses, tough regulations for the sale of certain products, low prices, and limited financial and business support to enable them to innovate or add value to local products. A mood of pessimism was evident; community members in all four communities argued that:

"emigration has always been a problem in the area, young people nearly all migrate away", that the "younger generations are trying to leave the area, others have resigned themselves to a future without prospects", or that "the brightest and best of the younger generations have all left the area."

A lack of suitable courses in schools and colleges to prepare young people for local jobs has exacerbated this issue. Despite this loss of young people from some areas, many family farms remained productive due to the availability of cheap labor from international in-migration (from Eastern Europe, for example). In addition, this period saw the beginnings of a new trend of return migration as some young people returned to farming as innovators, investing money made in other sectors back into their home area. This new trend offers the potential for a new cycle of technology-driven innovation in agriculture, but with much more awareness of global markets and an understanding of the potential for entrepreneurship based on the value local products. This new trend echoes the cultural changes occurring in the search to recover local rural identity, which started in the previous period and continued and expanded into a cultural re-evaluation of traditional farming activities and community cooperation initiatives (GAS, bio-districts). The birth of new grassroots networks (organic producer associations, young people's cooperatives) which run alongside institutional networks (LEADER programmes, Territorial Pacts) signaled a partial strengthening of social capital and networks, even though these are small-scale initiatives founded on criticisms of the dominant models of consumption and production. This more complex and intricate mode of governance has the potential to engender change, although initiatives are not always translated into effective bottom-up actions.

This period was characterized by a rapid decline in soil quality. In upland areas, lack of maintenance and land abandonment led to the collapse of many of the terraces, which had provided important slope stability as well as being culturally important landscape features, despite regional policy initiatives to identify and mitigate landslide risk (which were largely a paper exercise). The effects of this decline in management, which started in Period 2, ere felt more intensely in Period 3 and impacted widely on the economic sectors of the SES, such as tourism in the upland communities. Conversely, lowland tourism continued to grow in urban areas along the coast, which added to the dissatisfaction felt by upland rural communities. The few initiatives already in place to restore terraces (for example, measure 216 of the Rural Development Plan) or simple routine maintenance by farmers (cross compliance or voluntary actions) represented tiny actions in a landscape characterized by abandonment. On the plains, commercial greenhouse expansion and urban development driven by demand for tourism infrastructure have led to further reductions in the land available for agriculture.

\section{Discussion}

The timelines for the three periods described above highlight the complexity of the events and activities occurring at multiple spatial and temporal scales across the Alento SES. Looking back on these events and activities, however, patterns are clearly visible, as are the threads that tie actions together, and we can trace their impacts on resilience across time and space.

At the start of Period 1, the Alento SES was experiencing much the same trends as those seen across the rest of southern Italy (rural out-migration to industrialized centres during the post-war economic revival), mainly overlaid by national and supra-national trends as the agricultural sector underwent a process of modernization and reorganization. The social, cultural, and economic 
impacts of these macro-scalar changes were seen to affect community resilience, in particular through ongoing rural depopulation and outmigration as a result of much lower demand for agricultural labor, and the beginning of the breakdown in traditional practices such as transhumance. In particular, these agricultural changes led to weakening of previously strong intra-community ties and the loss of trust and co-operation between upland communities and those in the plains. This loss of trust undermined resilience and ultimately led, in Period 3, to a population imbalance and the continued loss of services. Reduction in demand for land in upland areas also continued to undermine these communities, resulting in the disappearance of local disease-resistant olive cultivars, loss of traditional terrace maintenance, and ultimately leading to landslides, landscape instability, and further isolation. Conversely, at the regional level, the resilience of the SES was strengthened through agricultural reform, resulting in better efficiency and improved connectivity to national and international markets. The spare capacity in the labor force also acted to buffer the system, providing adaptability and opportunities for innovation, particularly for lowland areas of the SES.

The existence of spare labor capacity enabled the growth and consolidation of new tourism markets, including agri-tourism, in Period 2, along with investment in major infrastructure projects. Improvements to water supply infrastructure widened the range of opportunities available to large agricultural businesses, removing a critical lock-in and providing a boost to other sectors such as the construction industry, which continued into Period 3 and was boosted again by increased availability of financial capital. Again, the spare labor capacity in the agricultural sector enabled small family-run farms on the plains to capitalize on these new opportunities and take off-farm jobs, thereby also buffering them against lower market prices and declining yields, all of which supported an increase in the resilience of the SES.

As can be seen in all three time periods, however, the economic advantages were geographically stratified, with upland communities having significantly less access to these new opportunities as a result of continuing landslides and poor transport infrastructure. Culturally, these communities were also stagnating, further undermining their resilience. New educational reforms in Period 1 went some way towards improving the lives of young people in the upland communities such as San Mauro and Stella Cilento, but once they completed secondary school, their opportunities became significantly narrowed as a result of few job opportunities outside of agriculture. It was not until Period 3 that opportunities would begin to increase through the designation of the National Park and a resurgence in interest in "natural" products and organic olive production, although this small increase in the quality of economic and social factors seems to have had little impact on community resilience as yet.

The changes outlined in the three periods discussed above clearly show that the resilience of the Alento SES has been affected by many different processes operating at multiple spatial levels and across temporal scales, and that it is geographically stratified. The interplay between factors in each of the domains is complex and easily disturbed, yet lock-ins have prevented actors from responding to change. As can be seen within each period, ripple effects caused by negative changes to factors in one domain have spread out to impact on other domains (for example, the decline in traditional family upland farms, which led to a lack of terrace maintenance and thence increased landslides and soil erosion). These ripples have been geographically uneven and have reinforced existing or historic inequalities. However, these ripple effects not only caused an imbalance between domains (a decrease or an increase in some specific factors), but also changes in their quality. In some cases, promoting inappropriate and poor quality actions has been much worse in terms of improvements than doing nothing, because they have locked areas of the SES into undesirable pathways from which it has been difficult to escape [41]. The evidence from the Alento SES also showed that sectors and communities can be locked into specific pathways of decision-making, which can lead to increased or uneven vulnerability over long timescales [40,59]. Such lock-ins have been particularly evident in the context of economic lock-ins (for example, the dependency of commercial lowland farms on subsidies and technology to support monocultures and low quality olive production), structural lock-ins (such as farms caught in complex producer-marketing agro-commodity chains) 
and, perhaps most importantly, socio-psychological lock-ins linked to an inability to see (let alone implement) alternative development pathways. The upland communities in the Alento SES can be seen to be in a vicious circle of tightening lock-ins that have further shoehorned stakeholders into increased dependency on specific subsidy-based or economically precarious activities.

The difficulties faced by these areas are closely interconnected with social memory and, in particular, a dependence on skills and knowledge pathways associated with long-held values [60]. This social memory is threatened by various processes, in particular outmigration of young people, land abandonment, water mismanagement, and, to some extent, tourism [40,41]. The resilience of the SES and its constituent communities is also affected by policy corridors-i.e., political and policy-related pathways of decision-making that are not always to the benefit of marginal or isolated and ageing communities $[43,61]$. Thus, while some of the CAP rural development and agri-environmental measures have undoubtedly helped the survival of more vulnerable communities within the Alento, other policies have had negative effects on individual livelihoods through misguided goals. Particular examples are CAP policies aimed at intensification and modernization of olive production and policies that may wrongly target specific populations, such as those favoring the production of inappropriate crops. Negative policy impacts can also be seen in policies that have been formulated and implemented without sufficient input from local knowledge and expertise (e.g., policies attempting to regulate water and irrigation management processes that have previously relied on centuries of local knowledge) [62-65].

Supporting improvement in the resilience of socio-ecological systems must, therefore, be accompanied by knowledge- and awareness-raising schemes (important factors within the social domain), training and education about locally relevant best-practice management, and gradually building positive social memory whilst also supporting sustainable innovation. It is also important to reflect on the evidence from the Alento across the three periods: that different stakeholder groups have been affected in very different ways by trajectories of change in the SES, as can be seen in the different expressions of resilience at various spatial and temporal scales in the Alento. This aspect is particularly important because socio-ecological systems are characterized by complex and sometimes obscure stakeholder interactions (both horizontal and vertical interlinkages) $[5,66,67]$. Assessing the impact of changes in the domains and their constituent components on socio-ecological and community resilience, therefore, required subtle insight into the highly differentiated stakeholder livelihood pathways found in complex systems. It is essential to understand in detail the opportunities and barriers that exist for stakeholders to either control the trajectory of the system (i.e., change its precariousness) or change the processes in response to dynamics at other scales (for example, the Panarchy response [6]). A key part of any evaluation of resilience in an SES is, therefore, to use a broad range of both qualitative and quantitative data and to work with local stakeholders to understand and support their ability to anticipate and respond to change, to minimize, cope with, and recover from the consequences of change $[30,68,69]$.

\section{Conclusions}

The purpose of this research was to explore the complex and shifting relationships between various factors in the economic, natural, social, cultural, and political domains in the Alento socio-ecological system, an area that can be considered paradigmatic of the marginalization processes impacting rural areas in Europe and beyond. A range of qualitative and quantitative data was used to assess the impact of those dynamic processes on the resilience of the area to land degradation over an extended time period. The results suggest that the capacity of this socio-ecological system to withstand internal and external shocks is geographically differentiated, and dependent on the availability and use of critical factors of the five domains and on the strength of their interactions across space and time.

In terms of assessing resilience to land degradation, this paper showed that it is crucial to study human-environment systems as interlinked and inherently complex $[29,31,70]$. If we want to understand why land degradation continues to happen, we must look closely at multiple aspects of the social, cultural, political/institutional, and natural processes occurring and impacting across 
geographic scales [47]. However, because of the differences in temporal speeds between human and natural responses to land degradation, we must also examine much longer timescales, as we have done in this paper, to enable us to trace the relationships between human actions and their impacts on the sustainability of the system $[6,10,41]$. The results discussed in this paper also highlight the importance of promoting place-based policies specifically tailored to local socio-ecological needs and adaptable enough to enable the linkages and connections between domain components to be recognized. The current shift in the EU towards more performance-oriented policies (instead of being focused on compliance) could act as a fundamental impetus to move towards more locally appropriate responses if the communities in which they are implemented are given the opportunity to effectively engage in debate and discussion before such policies are imposed.

Author Contributions: This paper is a result of a joint work. All components of the paper have been equally shared. All authors read and approved the final manuscript.

Funding: This study was financed by the European Union project "Land and Ecosystem Degradation and Desertification: Assessing the Fit of Responses-LEDDRA" [FP7-ENV-2009-1 Collaborative Project, No. 243857; 2010-2014].

Acknowledgments: The authors wish to thank T. Absalom and J. Quinn for Figure 1 cartography.

Conflicts of Interest: The authors declare no conflict of interest.

\section{Appendix A}

Table A1. Selected Domains, Factors and Measured Characteristics.

\begin{tabular}{|c|c|c|}
\hline Domain & Factors + & Measured Characteristics/Operational Measures \\
\hline \multirow[t]{5}{*}{ Natural } & Climate & Rainfall, temperature, aridity, evapotranspiration \\
\hline & Geology/Geomorphology & Rock types, landforms, slopes \\
\hline & Soils & Soil types, depth, texture, soil organic matter \\
\hline & Water resources & $\begin{array}{l}\text { Water bodies, network, water quantity, quality, } \\
\text { water balance }\end{array}$ \\
\hline & Land cover & Land cover types \\
\hline \multirow[t]{7}{*}{ Economic } & Production & $\begin{array}{l}\text { GDP by sector; Added Value by sector; Exports by sector; } \\
\text { Employment by sector; Number of enterprises (farm and } \\
\text { other enterprises); Number of houses built; AUA, } \\
\text { Off farm job }\end{array}$ \\
\hline & Financial & Subsidies; Remittances; Bank deposits; Disposable income \\
\hline & Technology & $\begin{array}{l}\text { Fertilizers, pesticides, mechanization, etc.; } \\
\text { communication technology, IT }\end{array}$ \\
\hline & Landesque & Terraces, irrigation systems \\
\hline & Physical & $\begin{array}{l}\text { Housing, farm structures, factories, roads, dams, } \\
\text { communication, energy, irrigation. Schools, hospitals }\end{array}$ \\
\hline & Animal (Livestock) & Livestock unit (LSU) \\
\hline & $\begin{array}{l}\text { Plants and machinery/Land } \\
\text { use }\end{array}$ & Plant used in production; Types, extent, intensity \\
\hline \multirow[t]{2}{*}{ Social } & Social networks & Social, civic, professionals groups \\
\hline & $\begin{array}{l}\text { Demographics and } \\
\text { Population }\end{array}$ & Size, age-sex, nationality characteristics; net migration \\
\hline Cultural & Education & $\begin{array}{l}\text { Formal and informal education, skills, competences, } \\
\text { experience, local environmental knowledge }\end{array}$ \\
\hline Institutional & Institutions/governance & $\begin{array}{l}\text { Administrative organizations, formal and informal } \\
\text { institutions, political groups/parties }\end{array}$ \\
\hline
\end{tabular}

† NB. Some factors were not considered in the analysis as they showed no significant changes along the time span considered. Factors shown in red text are those for which diachronic analysis was used. Source: Adapted from (LEDDRA Partners 2012 [71]). 
Table A2. Period 1-1950s to 1970s (Migration and efficiency imperative-transition).

\begin{tabular}{|c|c|c|}
\hline Domain & Factors & \\
\hline \multirow[t]{2}{*}{ Natural } & Water resources & $\begin{array}{l}\text { Barely adequate facilities for distribution of water along } \\
\text { an irrigation network limited expansion of production, } \\
\text { especially on the plains. }\end{array}$ \\
\hline & Soils & $\begin{array}{l}\text { Only } 16 \% \text { of the SES was classified as "high" or "very } \\
\text { high" quality soil, while } 40 \% \text { is classed as "low quality". } \\
\text { Steeply sloping land posed the biggest challenge as very } \\
\text { few crops are suited to such terrain. }\end{array}$ \\
\hline \multirow[t]{3}{*}{ Economic } & Production & $\begin{array}{l}\text { Decrease in labor employed in agriculture (from } 6968 \text { to } \\
4275 \text { ). } \\
\text { Reduction of UAA (from } 41,827 \text { to } 23,025 \text { ha). } \\
\text { Supra-local scale: } \\
\$ 13 \text { billion Marshall Plan for post war infrastructure } \\
\text { (European Recovery Plan) from end of World War II up } \\
\text { until } 1951 \text {. } \\
1975 \text { European Regional Development Fund set up. }\end{array}$ \\
\hline & Financial & $\begin{array}{l}\text { Increase in availability of capital due to remittances and } \\
\text { subsidies, plus targeted development Fund for the South } \\
\text { (law n.646 "Cassa per il Mezzogiorno). }\end{array}$ \\
\hline & Physical & Increase in infrastructure due to Fund for South. \\
\hline \multirow[t]{2}{*}{ Social } & Social networks & Tight local community networks and good levels of trust. \\
\hline & Population & $\begin{array}{l}\text { Decrease, particularly in rural upland areas (from } 46,606 \\
\text { to } 44,086 \text { ). }\end{array}$ \\
\hline Cultural & Education & $\begin{array}{l}\text { Increase in those completing secondary-level education } \\
\text { (from } 63 \% \text { to } 80 \% \text { ). }\end{array}$ \\
\hline Institutional & Institutions/governance & $\begin{array}{l}\text { Increasing opportunity for regional decision-making at } \\
\text { the end of the period due to impending governance } \\
\text { reforms. } \\
\text { Law } 10 \text { August 1950, n. } 646 \text { "Cassa per il Mezzogiorno - } \\
\text { Fund for South"; Infrastructure works and irrigation } \\
\text { works. } \\
\text { Law } 21 \text { October 1950, n. 841. "Legge Stralcio"; } \\
\text { expropriation of land from absent landowners and } \\
\text { redistribution to farmers. } \\
\text { Supra-local scale: } \\
1957 \text { Treaty of Rome, Common Agricultural Market } \\
\text { established. } \\
\text { Law } 31 \text { December } 1962 \text { n. } 1859 \text { "Reform of secondary } \\
\text { schools" Starting from } 1 \text { January } 1963 . \\
\text { Regulation CE } 727 / 70 \text { on liberalization of Tobacco-end of } \\
\text { State monopoly. } \\
\text { Mansholt Plan 1972, European directives passed on } \\
\text { modernization of agricultural holdings and training for } \\
\text { farmers. }\end{array}$ \\
\hline
\end{tabular}


Table A3. Period 2-1980 to 2000 (Local off-farm jobs—stable state).

\begin{tabular}{|c|c|c|}
\hline Domain & Factors & \\
\hline Natural & Water resources & $\begin{array}{l}\text { Improvements to water resource availability through construction } \\
\text { of a series of dams (with a storage capacity of about } 30,500,000 \\
\text { cubic meters). }\end{array}$ \\
\hline \multirow[t]{6}{*}{ Economic } & Production & $\begin{array}{l}\text { Increasing off farm job opportunities due to economic expansion in } \\
\text { coastal and lowland areas. Farmers gained work in other sectors } \\
\text { (from } 1644 \text { in the } 1980 \text { s to } 2067 \text { in the 1990s). }\end{array}$ \\
\hline & Financial & $\begin{array}{l}\text { Improved availability due to funding from Territorial Pacts and } \\
\text { CAP subsidies 1994-1999: POP (Pluri-Found Operative Plan) } \\
\text { 1994-1999 interventions for the modernization of the olive oil sector } \\
\text { 1995: The Territorial Pacts (TP) were introduced under the } \\
\text { financing law of 1995. A TP is a "contract" signed by groups of } \\
\text { townships with the aim to increase cooperation and private and } \\
\text { public investments. } \\
\text { Supra-local scale: } \\
\text { 1991: LEADER was first introduced as a pilot initiative. } \\
\text { 1992: MacSharry reform of European CAP (a shift from production } \\
\text { subsidies to area payments). } \\
\text { 1992. The devaluation of the Lira (produced a system of } \\
\text { over-compensation for cereal production, which continued with } \\
\text { intensive production systems and surpassed the expectations } \\
\text { under the reform). } \\
\text { 1998: Regulation 1638/1998, of } 20 \text { July } 1998 \text { introduced a shift in the } \\
\text { basis of the olive oil support system, from production to number of } \\
\text { trees. }\end{array}$ \\
\hline & Technology & $\begin{array}{l}\text { Increasing mechanization due to increased finance availability. } \\
\text { Number of tractors increased from } 676 \text { to } 744 \text {. Change in } \\
\text { availability of olive cultivars. }\end{array}$ \\
\hline & Landesque & $\begin{array}{l}\text { Area with potential for irrigation increases from } 3095.91 \text { ha in } 1990 \\
\text { to } 3611.43 \text { ha in } 2000 \text {. }\end{array}$ \\
\hline & Physical & Increase in infrastructure due to construction industry expansion. \\
\hline & Plant/Land use & $\begin{array}{l}\text { Olive groves expand from } 7596 \text { ha to } 7959 \text { ha; orchards increase } \\
\text { from } 408 \text { ha to } 1284 \text { ha. }\end{array}$ \\
\hline Social & Social networks & $\begin{array}{l}\text { Changes made by both National Park institutions and negotiated } \\
\text { planning governance model: level of conflict increased but the } \\
\text { social exchanges also intensified. }\end{array}$ \\
\hline Cultural & & $\begin{array}{l}\text { 1981: The township of Pollica was chosen as a sample site to study } \\
\text { the } \\
\text { Mediterranean diet. } \\
\text { Supra-local scale: Between } 1999 \text { and 2001, the process of full } \\
\text { decentralization of public administration was completed (Reform } \\
\text { of Titolo V of the Italian Constitution) and this impacted on the } \\
\text { cultural attitude of the SES. }\end{array}$ \\
\hline Institutional & Institutions/governance & $\begin{array}{l}\text { Major devolution of power from state to regions significantly } \\
\text { increased } \\
\text { decision-making power at local level. } \\
\text { 1991: Law no.169 of 2/2/1991: local initiatives to apply for official } \\
\text { recognition of PDO status (Protected Denomination of Origin) for } \\
\text { Cilento olive oil under the law. } \\
\text { 1991: Institution of the National Park of Cilento and Vallo di Diano } \\
\text { 1992: Official delineation of the Park's boundaries. } \\
\text { 1989: Approval of the Interim plan for land-use regulations and } \\
\text { monitoring of landslides as a result of national law no. 183/1989. } \\
\text { 15\% of land surface was classified as affected by landslides. } \\
\text { Supra-local scale: 1984: enforcement of Regional Law no. } 41 \text { of the } \\
\text { 28/08/1984 "Interventi per favorire l'agriturismo in Campania" } \\
\text { (support to agritourism). }\end{array}$ \\
\hline
\end{tabular}


Table A4. Period 3-2000-2015 (Land abandonment-transition).

\begin{tabular}{|c|c|c|}
\hline Domain & Factors & \\
\hline Natural & Soils & $\begin{array}{l}\text { Collapsing terraces led to significant soil loss and increased } \\
\text { vulnerability to landslips. }\end{array}$ \\
\hline \multirow[t]{3}{*}{ Economic } & Production & $\begin{array}{l}\text { Reduction of UAA from } 18,373 \text { to } 14,932 \text { ha. } \\
\text { Reduction in number of farms from } 7718 \text { to } 5136 \text {. } \\
\text { Supra-local scale: } \\
\text { Single payment schemes (SPS) were introduced in } 2003 \text { (Council } \\
\text { Resolution EC no. 1782/2003). }\end{array}$ \\
\hline & Landesque & $\begin{array}{l}\text { 2007-2013: Introduction of a specific measure under the Rural } \\
\text { Development Program (Measure 216) to restore the derelict } \\
\text { terraces introduced (total surface area under intervention of } \\
\text { Measure } 216 \text { Action B, Restoration and/or extension and dry } \\
\text { stone walls, terraces, and pre-existing embankments was } 195.50 \\
\text { hectares). }\end{array}$ \\
\hline & Physical & $\begin{array}{l}\text { Roads in poor condition led to difficulty moving products and } \\
\text { increased transport costs (according to information provided by } \\
\text { the local maintenance agency, in 2010, one third of the road } \\
\text { network was classed as being in "a bad state of maintenance", } \\
\text { while around half was classed as being in a "medium state of } \\
\text { maintenance"). }\end{array}$ \\
\hline \multirow[t]{2}{*}{ Social } & Population & $\begin{array}{l}\text { Ageing farm population, lack of new entrants into farming, and } \\
\text { low levels of skills being passed on ( } 2007 \text { official statistics showed } \\
\text { the lowest percentage of young farmers in the area compared to } \\
\text { the region as a whole. The latter was itself lower than the } \\
\text { national average (farmers younger than } 39 \text { represented only } 5.9 \% \\
\text { compared to } 8 \% \text { nationally-Ismea } 2011) \text { ). }\end{array}$ \\
\hline & Social networks & $\begin{array}{l}\text { 2009: The multi-vocational European Bio-District Network } \\
\text { (involving Agriculture, Environment, Culture, Social, } \\
\text { Eco-tourism, Gastronomy) was established. It linked organic } \\
\text { farms (around 400), producer organizations, local } \\
\text { administrations, bio-restaurants, eco-tourism operators, and } \\
\text { consumers (via the GAS Gruppi di Acquisto Solidale-Solidarity } \\
\text { Base Purchasing Groups). }\end{array}$ \\
\hline Cultural & & $\begin{array}{l}\text { 2010: The recognition of the cultural significance of the } \\
\text { Mediterranean diet, born within the study area, by UNESCO as } \\
\text { Patrimony of Humanity. }\end{array}$ \\
\hline Institutional & Institutions/governance & $\begin{array}{l}\text { Proliferation of plans, projects, and programming activities led to } \\
\text { a partial overlapping in jurisdiction of the administrative units } \\
\text { present within the local territory. One of the common elements of } \\
\text { all these types of programming and plans in place was the central } \\
\text { importance in collective decision making, A complex and } \\
\text { intricate structure of governance left the potential for change high, } \\
\text { although this was not translated into effective bottom-up actions. }\end{array}$ \\
\hline
\end{tabular}

\section{References}

1. Briassoulis, H. Response assemblages and their socioecological fit: Conceptualizing human responses to environmental degradation. Dialogues Hum. Geogr. 2017, 7, 166-185. [CrossRef]

2. Wynants, M.; Kelly, C.; Mtei, K.; Munishi, L.; Patrick, A.; Rabinovich, A.; Nasseri, M.; Gilvear, D.; Roberts, N.; Boeckx, P. Drivers of increased soil erosion in East Africa's agro-pastoral systems: Changing interactions between the social, economic and natural domains. Reg. Environ. Chang. 2019, 19, 1909-1921. [CrossRef]

3. Borrelli, P.; Robinson, D.A.; Fleischer, L.R.; Lugato, E.; Ballabio, C.; Alewell, C.; Meusburger, K.; Modugno, S.; Schütt, B.; Ferro, V. An assessment of the global impact of 21st century land use change on soil erosion. Nat. Commun. 2017, 8, 2013. [CrossRef] [PubMed]

4. Knickel, K.; Redman, M.; Darnhofer, I.; Ashkenazy, A.; Calvão Chebach, T.; Šūmane, S.; Tisenkopfs, T.; Zemeckis, R.; Atkociuniene, V.; Rivera, M.; et al. Between aspirations and reality: Making farming, 
food systems and rural areas more resilient, sustainable and equitable. J. Rural Stud. 2017, 59, 197-210. [CrossRef]

5. Berkes, F.; Folke, C. (Eds.) Linking Social and Ecological Systems: Management Practices and Social Mechanisms for Building Resilience; Cambridge University Press: Cambridge, UK, 1998.

6. Gunderson, L.; Holling, C. (Eds.) Panarchy: Understanding Transformations in Human and Natural Systems; Island Press: Washington, DC, USA, 2002; p. 507.

7. Buikstra, E.; Ross, H.; King, C.A.; Baker, P.G.; Hegney, D.; McLachlan, K.; Rogers-Clark, C. The components of resilience: Perceptions of an Australian rural community. J. Community Psychol. 2010, 38, 975-991. [CrossRef]

8. Berkes, F.; Ross, H. Community Resilience: Toward an Integrated Approach. Soc. Nat. Resour. 2012, 26, 5-20. [CrossRef]

9. Wilson, G.A. Community Resilience and Environmental Transitions; Earthscan: London, UK, 2012; p. 251.

10. Kelly, C.; Ferrara, A.; Wilson, G.A.; Ripullone, F.; Nolè, A.; Harmer, N.; Salvati, L. Community resilience and land degradation in forest and shrubland socio-ecological systems: Evidence from Gorgoglione, Basilicata, Italy. Land Use Policy 2015, 46, 11-20. [CrossRef]

11. Holling, C. Resilience and stability of ecological systems. Annu. Rev. Ecol. Syst. 1973, 4, 1-23. [CrossRef]

12. Folke, C.; Carpenter, S.; Elmqvist, T.; Gunderson, L.; Holling, C.; Walker, B.; Bengtsson, J.; Berkes, F.; Colding, J.; Danelle, K.; et al. Resilience and Sustainable Development: Building Adaptive Capacity in a World of Transformations; Scientific Background Paper on Resilience for the process of the World Summit on Sustainable Development; The Environmental Advisory Council to the Swedish Government: Stockholm, Sweden, 2002.

13. Pelling, M. The Vulnerability of Cities: Natural Disasters and Social Resilience; Earthscan: London, UK, 2003.

14. Adger, W.N.; Hughes, T.P.; Folke, C.; Carpenter, S.; Rockstrom, J. Social-ecological resilience to coastal disasters. Science 2005, 309, 1036-1039. [CrossRef]

15. Anderies, J.M.; Walker, B.H.; Kinzig, A.P. Fifteen weddings and a funeral: Case studies and resilience-based management. Ecol. Soc. 2006, 11, 21. [CrossRef]

16. Gunderson, L.H.; Carpenter, S.R.; Folke, C.; Olsson, P.; Peterson, G. Water RATs (Resilience, Adaptability, and Transformability) in Lake and Wetland Social-Ecological Systems. Ecol. Soc. 2006, 11, 16. [CrossRef]

17. Hopkins, R. The Transition Handbook: From Oil Dependency to Local Resilience; Green Book: Dartington, UK, 2008.

18. Kajoba, G.M. Vulnerability and Resilience of Rural Society in Zambia: From the Viewpoint of Land Tenure and Food Security; Working Paper on Social-Ecological Resilience Series No. 2008-003; Research Institute for Humanity and Nature: Lusaka, Zambia, 2008; p. 41.

19. Masten, A.S.; Obradovic, J. Disaster preparation and recovery: Lessons from research on resilience in human development. Ecol. Soc. 2008, 13, 9. [CrossRef]

20. Cinner, J.; Fuentes, M.M.P.B.; Randriamahazo, H. Exploring social resilience in Madagascar's Marine Protected Areas. Ecol. Soc. 2009, 14, 41-60. [CrossRef]

21. Resilience Alliance. Urban Resilience. 2009. Available online: www.resalliance.org (accessed on 12 September 2019).

22. Darnhofer, I.; Fairweather, J.; Moller, H. Assessing a farm's sustainability: Insights from resilience thinking. Int. J. Agric. Sustain. 2010, 8, 186-198. [CrossRef]

23. Fleischman, F.D.; Boenning, K.; Garcia-Lopez, G.A.; Mincey, S.; Schmitt-Harsh, M.; Daedlow, K.; Lopez, M.C.; Basurto, X.; Fischer, B.; Ostrom, E. Disturbance, Response, and Persistence in Self-Organized Forested Communities: Analysis of Robustness and Resilience in Five Communities in Southern Indiana. Ecol. Soc. 2010, 15, 9. [CrossRef]

24. Berardi, G.; Green, R.; Hammond, B. Stability, sustainability, and catastrophe: Applying resilience thinking to U. S. agriculture. Hum. Ecol. Rev. 2011, 18, 115-125.

25. Burkhard, B.; Gee, K. Establishing the Resilience of a Coastal-marine Social-ecological System to the Installation of Offshore Wind Farms. Ecol. Soc. 2012, 17, 32. [CrossRef]

26. Folke, C. Resilience: The emergence of a perspective for social-ecological systems analyses. Glob. Environ. Chang. 2006, 16, 253-267. [CrossRef]

27. Diamond, J. Collapse: How Societies Choose to Fail or Survive; Penguin: London, UK, 2005.

28. Stump, D. Ancient and backward or long-lived and sustainable? The role of the past in debates concerning rural livelihoods and resource conservation in eastern Africa. World Dev. 2010, 38, 1251-1262. [CrossRef] 
29. Davidson, J.L.; Jacobson, C.; Lyth, A.; Dedekorkut-Howes, A.; Baldwin, C.L.; Ellison, J.C.; Holbrook, N.J.; Howes, M.J.; Serrao-Neumann, S.; Singh-Peterson, L. Interrogating resilience: Toward a typology to improve its operationalization. Ecol. Soc. 2016, 21, 27. [CrossRef]

30. Magis, K. Community resilience: An indicator of social sustainability. Soc. Nat. Resour. 2010, 23, 401-416. [CrossRef]

31. Folke, C.; Carpenter, S.R.; Walker, B.; Scheffer, M.; Chapin, T.; Rockstrom, J. Resilience thinking: Integrating resilience, adaptability and transformability. Ecol. Soc. 2010, 15, 20. [CrossRef]

32. Cumming, G.S.; Cumming, D.H.M.; Redman, C.L. Scale Mismatches in Social-Ecological Systems: Causes, Consequences and Solutions. Ecol. Soc. 2006, 11, 14. [CrossRef]

33. Zurlini, G.; Riiters, K.; Zaccarelli, N.; Petrosillo, I.; Jones, K.B.; Rossi, L. Disturbance patterns in a socio-ecological system at multiple scales. Ecol. Complex. 2006, 3, 119-128. [CrossRef]

34. Reed, M.S.; Buenemann, M.; Atlhopheng, J.; Akhtar-Schuster, M.; Bachmann, F.; Bastin, G.; Bigas, H.; Chanda, R.; Dougill, A.J.; Essahli, W.; et al. Cross-scale monitoring and assessment of land degradation and sustainable land management: A methodological framework for knowledge management. Land Degrad. Dev. 2011, 22, 261-271. [CrossRef]

35. Wilson, G.A. From productivism to post-productivism and back again? Exploring the (un)changed natural and mental landscapes of European agriculture. Trans. Inst. Br. Geogr. 2001, 26, 77-102. [CrossRef]

36. Robinson, G. Geographies of Agriculture: Globalisation, Restructuring and Sustainability; Pearson: Harlow, UK, 2004.

37. Wilson, G.A.; Juntti, M. (Eds.) Unravelling Desertification: Policies and Actor Networks in Southern Europe; Wageningen Academic Publishers: Wageningen, The Netherland, 2005; p. 246.

38. Wilson, G.A. Multifunctional Agriculture: A Transition Theory Perspective; CAB International: Wallingford, UK, 2007.

39. Wilson, G.A. Community Resilience and Social Memory. Environ. Values 2015, 24, 227-257. [CrossRef]

40. Wilson, G.A.; Quaranta, G.; Kelly, C.; Salvia, R. Community resilience, land degradation and endogenous lock-in effects: Evidence from the Alento region, Campania, Italy. J. Environ. Plan. Manag. 2016, 59, 518-537. [CrossRef]

41. Wilson, G.A.; Kelly, C.L.; Briassoulis, H.; Ferrara, A.; Quaranta, G.; Salvia, R.; Detsis, V.; Curfs, M.; Cerda, A.; El-Aich, A.; et al. Social memory and the resilience of communities affected by land degradation. Land Degrad. Dev. 2016, 28, 383-400. [CrossRef]

42. Sutherland, L.-A.; Darnhofer, I.; Wilson, G.; Zagata, L. (Eds.) Transition Pathways Towards Sustainability in Agriculture: Case Studies from Europe; CABI: Wallingford, UK, 2014.

43. Quaranta, G.; Salvia, R. Sustainability patterns and policy fit: Evidences from a mixed approach applied in a euromediterranean area. Riv. di Studi Sulla Sostenibilità 2014, 2, 59-81. [CrossRef]

44. Becker, H. Cases, causes, conjunctures, stories and imagery. In Case Study Method: Key Issues, Key Texts; Gomm, R., Hammersley, M., Foster, P., Eds.; Sage: London, UK, 2000; pp. 223-233.

45. Polkinghorne, D. Narrative configuration in qualitative analysis. In Life History and Narrative; Hatch, J.A., Wisniewski, R., Eds.; The Falmer Press: London, UK, 1995; pp. 5-23.

46. Resilience Alliance. Assessing and Managing Resilience in Social-Ecological Systems: A Practitioners Workbook The Resilience Alliance. Volume 1 Version 1.084. 2007. Available online: http://www.resalliance. org/3871.php (accessed on 17 September 2019).

47. Briassoulis, H. The Socio-ecological Fit of Human Responses to Environmental Degradation: An Integrated Assessment Methodology. Environ. Manag. 2015, 56, 1448-1466. [CrossRef] [PubMed]

48. Ferrara, A.; Kelly, C.; Wilson, G.A.; Nolè, A.; Mancino, G.; Bajocco, S.; Salvati, L. Shaping the role of "fast" and "slow" drivers of change in forest-shrubland socio-ecological systems. J. Environ. Manag. 2016, 169, 155-166. [CrossRef] [PubMed]

49. Rossi Doria, M. La Calabria Agricola e il Suo Avvenire. IL Ponte 1950, 8, 9.

50. Beguinot, C.; Galasso, G.; Petriccione, S.; Turco, C. Problemi demografici e questione meridionale. ESI 1959, $8,285$.

51. Levi, C. Christ Stopped at Eboli. The Story of a Year; Farrar Strauss and Company: New York, NY, USA, 1947.

52. Cafiero, S.; Marciani, G.E. Quarant'anni di intervento straordinario nel Mezzogiorno (1950-1989). Riv. Econ. del Mezzog. 1991, 2, 249-274.

53. INEA. L'economia Agraria Della Campania; Edizioni Italiane: Roma, Italy, 1948. 
54. INEA. La Distribuzione Della Proprietà Fondiaria in Italia: Tavole Statistiche: Campania; Edizioni Italiane: Roma, Italy, 1947.

55. Pascale, A. Radici \& Gemme. La Società Civile Delle Campagne DALL'UNITÀ ad Oggi; Cavinato Editore International: Brescia, Italy, 2013.

56. Di Nola, A.M. Mutazione culturale negli ultimi cinquant'anni. In Storia del Mezzogiorno; Editalia: Roma, Italy, 1994; p. 395.

57. Trigilia, C. Sviluppo Senza Autonomia. Effetti Perversi Delle Politiche nel Mezzogiorno; Il Mulino: Bologna, Italy, 1992.

58. Barca, F. L'Italia Frenata-Paradossi e Lezioni della Politica per lo Sviluppo; Donzelli Editore: Roma, Italy, 2006; p. 128.

59. Wilson, G.A. Community resilience: Path dependency, lock-in effects and transitional ruptures. J. Environ. Plan. Manag. 2013, 57, 1-26. [CrossRef]

60. Mistry, J.; Berardi, A.; Haynes, L.; Davis, D.; Xavier, R.; Andries, J. The role of social memory in natural resource management: Insights from participatory video. Trans. Inst. Br. Geogr. 2014, 39, 115-127. [CrossRef]

61. Briassoulis, H. Governing desertification in Mediterranean Europe: The challenge of environmental policy integration in multi-level governance contexts. Land Degrad. Dev. 2010, 22, 313-325. [CrossRef]

62. Berkes, F.; Colding, J.; Folke, C. Rediscovery of Traditional Ecological Knowledge as Adaptive Management. Ecol. Appl. 2000, 10, 1251-1262. [CrossRef]

63. Reed, M.S.; Dougill, A.J.; Taylor, M.J. Integrating local and scientific knowledge for adaptation to land degradation: Kalahari rangeland management options. Land Degrad. Dev. 2007, 18, 249-268. [CrossRef]

64. Von Glasenapp, M.; Thornton, T.F. Traditional ecological knowledge of Swiss alpine farmers and their resilience to socioecological change. Hum. Ecol. 2011, 39, 769-781. [CrossRef]

65. Ahlborg, H.; Nightingale, A.J. Mismatch Between Scales of Knowledge in Nepalese Forestry: Epistemology, Power, and Policy Implications. Ecol. Soc. 2012, 17, 16. [CrossRef]

66. Anderies, J.M.; Janssen, M.A.; Ostrom, E. A Framework to Analyze the Robustness of Social-ecological Systems from an Institutional Perspective. Ecol. Soc. 2004, 9, 18. [CrossRef]

67. Abel, N.; Cumming, D.H.M.; Anderies, J.M. Collapse and reorganization in social-ecological systems: Questions, some ideas and policy implications. Ecol. Soc. 2006, 11, 17. [CrossRef]

68. Resilience Alliance. Assessing resilience in social-ecological systems: A workbook for scientists. The Resilience Alliance. 2007. Available online: www.resalliance.org/3871.php (accessed on 17 September 2019).

69. Ostrom, E. A general framework for analyzing sustainability of social-ecological systems. Science 2009, 325, 419-422. [CrossRef]

70. Davidson, J.L.; van Putten, I.E.; Leith, P.; Nursey-Bray, M.; Madin, E.M.; Holbrook, N.J. Toward Operationalizing Resilience Concepts in Australian Marine Sectors Coping with Climate Change. Ecol. Soc. 2013, 18, 4. [CrossRef]

71. LEDDRA Partners. Assessing the Fit of Responses to LEDD: Theory, Assessment, Applications, Proposals, Knowledge Transfer: Methodology and First Synthesis; University of the Aegean: Mytilene, Lésvos, 2012; p. 76.

(C) 2019 by the authors. Licensee MDPI, Basel, Switzerland. This article is an open access article distributed under the terms and conditions of the Creative Commons Attribution (CC BY) license (http://creativecommons.org/licenses/by/4.0/). 